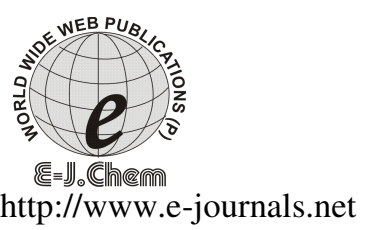

\title{
Infrared Irradiation Synthesis of Substituted 5-Oxo-1, 2, 3, 4, 5, 6, 7, 8-octahydroquinoline Derivatives under Solvent-free Conditions
}

\author{
SHU-XIANG WANG ${ }^{1}$, SHAO-BO GUO ${ }^{1}$, MING-ZHU GAO ${ }^{2}$, \\ JI-TAI LI ${ }^{1}$ and YUN-FEI DUAN ${ }^{1}$ \\ ${ }^{1}$ College of Chemistry and Environmental Science, \\ Hebei University, Baoding 071002, Hebei Province P. R. China. \\ ${ }^{2}$ Luck Film Corporation, P.R. China.
}

Received 18 May 2006; Accepted 23 June 2006.

\begin{abstract}
Infrared irradiation promoted the synthesis of substituted 5-oxo-1, 2, 3, 4, 5, 6, 7, 8-octahydroquinoline derivatives. The condensations of 5, 5-dimethyl-1, 3-cyclohexane-dione, 1, 3-diaryl-2-propen-1-one and ammonium acetate in the absence of solvent under infrared irradiation for $3 \mathrm{~h}$ gave the title compounds in $67.6 \% \sim 86.5 \%$ yields
\end{abstract}

Keywords: substituted 5-oxo-1, 2, 3, 4, 5, 6, 7, 8-octahydroquinoline derivatives; synthesis; solvent-free; infrared irradiation.

\section{Introduction}

1, 4-Dihydropyridines derivatives (1, 4-DHPs) possess a variety of biological activities. For example, they have been used as effective calcium channel modulators for the treatment of cardiovascular disorders ${ }^{1}$. 4-Substituted 1, 4-dihydropyridines are analogues of NADH coenzymes and can be used as medicine ${ }^{2}$. Much effort has been devoted to the synthesis of 1, 4-DHPs with different substituents ${ }^{3}$ or heteroatom ${ }^{4}$. The substituted 5-oxo-1, 2, 3, 4, 5, 6, 7, 8-octahydroquinoline derivatives are these chemical modifications rings. Therefore, preparation of it has attracted considerable attention in recent years.

Synthetic chemistry requires the consumption of energy and material. One of the greatest environmentally problematic aspects of organic synthetic chemistry is the use of solvent. The solvent has to be produced in another chemical process, which is involved in 
consuming energy and resources. Within the reaction the vast amount of solvent has to be heated or cooled, consuming large amount of energy, and has to be removed after completion of the reaction from the reaction mixture. A move away from the use of solvents in organic synthesis has led in some cases to improved results and more benign synthetic procedures ${ }^{5}$.

Infrared irradiation is a secure, cheap energy and can be easily obtained. Therefore, infrared irradiation in organic synthesis has been the focus of considerable attention in recent years. Guillermo ${ }^{6}$ reported a synthesis of 2-alkylbenzimidazoles and benzimidazol-2one by using a natural clay and infrared irradiation in solvent-free conditions. Alcerreca ${ }^{7}$ reported that several benzaldehydes were condensed with barbituric acid in absence of solvent under infrared irradiation, affording the corresponding 5-benzylidence barbituric acids. Obrador ${ }^{8}$ also synthesized benzylidenemalonoitriles, benzylidenecyanoacetamides and benzylidenecyanoacetic acids under infrared irradiation.

All of the results stated above spur us to study the possibility of synthesis of substituted 5-oxo-1, 2, 3, 4, 5, 6, 7, 8-octahydroquinoline derivatives (3) in the absence of solvent under infrared irradiation. Herein, we wish to report the results of the condensations of 5, 5dimethyl-1, 3-cyclohexane-dione, 1, 3-diaryl-2-propen- 1-one and ammonium acetate in solvent-free under infrared irradiation (Scheme 1).

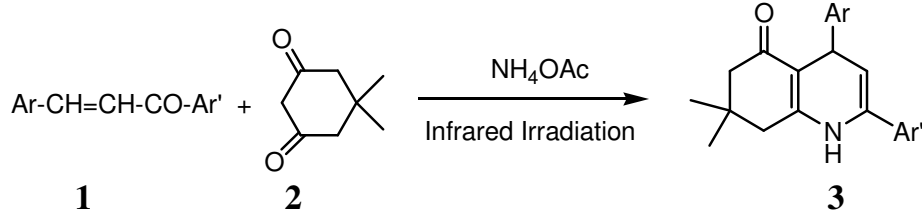

\section{Scheme 1}

\section{Experimental}

\section{Materials and Measurements}

Melting points are uncorrected. 5, 5-Dimethyl-1, 3-cyclohexane-dione was purchased from Fluka and was used without further purification. IR spectra were recorded on Bio-Rad FTS-40 spectrometer $(\mathrm{KBr}) .{ }^{1} \mathrm{HNMR}$ spectra were measured on Bruker AVANCE 400(400 MHz) spectrometer in $\mathrm{CDCl}_{3}$ using TMS as internal standard .The reaction was performed under W-10 IR lamp(with a nominal power of $500 \mathrm{~W}$; Beijing Zhen-xing lab instrument Co., Ltd.).

\section{General Procedure}

A dry $5 \mathrm{~mL}$ round-bottomed flask was charged with $1(1 \mathrm{mmol}), 2(1.25 \mathrm{mmol})$ and ammonium acetate $(2.5 \mathrm{mmol})$. The mixture was irradiated at a distance of $10 \mathrm{~cm}$ from an infrared lamp for $3 \mathrm{~h}$, and then cooled to room temperature. The solid was transferred with a small amount ethanol, and then filtered. The obtained solid was washed with water $(3 \times 10$ $\mathrm{mL}$ ). The crude product was purified by recrystallization from $95 \%$ ethanol to give 3 . The authenticity of the products was established by comparing their melting points, IR, ${ }^{1} \mathrm{HNMR}$ and elemental analysis.

3d: $\mathrm{v}_{\max } \mathrm{cm}^{-1} 3240,3020,2980,1610,1580,1500,830,760,690 ; \delta_{\mathrm{H}} 1.13\left(3 \mathrm{H}, \mathrm{s}, \mathrm{CH}_{3}\right)$, 1.24(3H, s, $\left.\mathrm{CH}_{3}\right), 2.28(1 \mathrm{H}, \mathrm{d}, J=16 \mathrm{~Hz}, \mathrm{CH}), 2.35(1 \mathrm{H}, \mathrm{d}, J=16 \mathrm{~Hz}, \mathrm{CH}), 2.40(1 \mathrm{H}, \mathrm{d}, J=16$ $\mathrm{Hz}, \mathrm{CH}), 2.51(1 \mathrm{H}, \mathrm{d}, J=16 \mathrm{~Hz}, \mathrm{CH}), 4.83(1 \mathrm{H}, \mathrm{d}, J=5.2 \mathrm{~Hz}, \mathrm{CH}), 5.37(1 \mathrm{H}, \mathrm{dd}, J=5.2 \mathrm{~Hz}$, $J=1.2 \mathrm{~Hz}, \mathrm{CH}), 5.84(1 \mathrm{H}, \mathrm{S}, \mathrm{NH}), 7.23-7.53(9 \mathrm{H}, \mathrm{m}, \mathrm{ArH})$. Anal. Calcd for $\mathrm{C}_{23} \mathrm{H}_{22} \mathrm{ClNO}: \mathrm{C}$, 75.91; H, 6.10; N, 3.85. Found(\%): C, 76.04; H, 5.94; N, 3.68. 
3e: $\mathrm{v}_{\max } \mathrm{cm}^{-1} 3250,3020,2990,2980,1620,1590,1500,810,690 ; \delta_{\mathrm{H}} 1.13\left(3 \mathrm{H}, \mathrm{s}, \mathrm{CH}_{3}\right)$, $1.14\left(3 \mathrm{H}, \mathrm{s}, \mathrm{CH}_{3}\right), 2.21(1 \mathrm{H}, \mathrm{d}, J=16 \mathrm{~Hz}, \mathrm{CH}), 2.27(1 \mathrm{H}, \mathrm{d}, J=16 \mathrm{~Hz}, \mathrm{CH}), 2.32(1 \mathrm{H}, \mathrm{d}, J=16$ $\mathrm{Hz}, \mathrm{CH}), 2.41(1 \mathrm{H}, \mathrm{d}, J=16 \mathrm{~Hz}, \mathrm{CH}), 4.67(1 \mathrm{H}, \mathrm{d}, J=5.2 \mathrm{~Hz}, \mathrm{CH}), 5.26(1 \mathrm{H}, \mathrm{dd}, J=5.2 \mathrm{~Hz}$, $\left.J^{\prime}=1.2 \mathrm{~Hz}, \mathrm{CH}\right), 5.83(1 \mathrm{H}, \mathrm{S}, \mathrm{NH}), 5.91\left(2 \mathrm{H}, \mathrm{s}, \mathrm{OCH}_{2} \mathrm{O}\right), 6.72-6.86(3 \mathrm{H}, \mathrm{m}, \mathrm{ArH}), 7.29-$ 7.45(4H, m, ArH). Anal. Calcd for $\mathrm{C}_{24} \mathrm{H}_{22} \mathrm{ClNO}_{3}: \mathrm{C}, 70.67 ; \mathrm{H}, 5.44 ; \mathrm{N}, 3.43$. Found(\%): $\mathrm{C}$, $70.86, \mathrm{H}, 5.23 ; \mathrm{N}, 3.15$.

3f: $\mathrm{v}_{\max } \mathrm{cm}^{-1} 3240,3060,2950,1660,1590,1490,820,760,690 ; \delta_{\mathrm{H}} 1.06\left(3 \mathrm{H}, \mathrm{s}, \mathrm{CH}_{3}\right)$, $1.13\left(3 \mathrm{H}, \mathrm{s}, \mathrm{CH}_{3}\right), 2.24(1 \mathrm{H}, \mathrm{d}, J=12 \mathrm{~Hz}, \mathrm{CH}), 2.31(1 \mathrm{H}, \mathrm{d}, J=12 \mathrm{~Hz}, \mathrm{CH}), 2.34(1 \mathrm{H}, \mathrm{d}, J=16$ $\mathrm{Hz}, \mathrm{CH}), 2.42(1 \mathrm{H}, \mathrm{d}, J=16 \mathrm{~Hz}, \mathrm{CH}), 4.75(1 \mathrm{H}, \mathrm{d}, J=5.2 \mathrm{~Hz}, \mathrm{CH}), 5.27(1 \mathrm{H}, \mathrm{dd}, J=5.2 \mathrm{~Hz}$, $J=1.2 \mathrm{~Hz}, \mathrm{CH}), 5.97(1 \mathrm{H}, \mathrm{S}, \mathrm{NH}), 7.14-7.39(4 \mathrm{H}, \mathrm{m}, \mathrm{ArH}), 7.41-7.44(5 \mathrm{H}, \mathrm{m}, \mathrm{ArH})$. Anal. Calcd for $\mathrm{C}_{23} \mathrm{H}_{22}$ ClNO: C, 75.79; H, 6.13; N, 3.99. Found(\%): C, 75.92, H, 6.09; N, 3.85.

3g: $\mathrm{v}_{\max } \mathrm{cm}^{-1} 3220,3060,2960,1660,1580,1490,820,770,690 ; \delta_{\mathrm{H}} 1.14\left(6 \mathrm{H}, \mathrm{s}, \mathrm{CH}_{3}\right)$, $2.23(1 \mathrm{H}, \mathrm{d}, J=12 \mathrm{~Hz}, \mathrm{CH}), 2.25(1 \mathrm{H}, \mathrm{d}, J=12 \mathrm{~Hz}, \mathrm{CH}), 2.38(1 \mathrm{H}, \mathrm{d}, J=16 \mathrm{~Hz}, \mathrm{CH}), 2.43(1 \mathrm{H}$, d, $J=16 \mathrm{~Hz}, \mathrm{CH}), 5.16(1 \mathrm{H}, \mathrm{d}, J=5.2 \mathrm{~Hz}, \mathrm{CH}), 5.25\left(1 \mathrm{H}, \mathrm{dd}, J=5.2 \mathrm{~Hz}, J^{\prime}=1.2 \mathrm{~Hz}, \mathrm{CH}\right)$, 5.96(1H, S, NH), 7.17-7.35(3H, m, ArH), 7.37(5H, m, ArH). Anal Calcd for $\mathrm{C}_{23} \mathrm{H}_{21} \mathrm{Cl}_{2} \mathrm{NO}$ : C, 69.17; H, 5.41; N, 3.71. Found(\%): C, 69.35, H, 5.31; N, 3.52.

3h: $\mathrm{v}_{\max } \mathrm{cm}^{-1} 3320,3040,2950,2870,1660,1580,1490,810,770 ; \delta_{\mathrm{H}} 1.05\left(3 \mathrm{H}, \mathrm{s}, \mathrm{CH}_{3}\right)$, $1.14\left(3 \mathrm{H}, \mathrm{s}, \mathrm{CH}_{3}\right), 2.22(1 \mathrm{H}, \mathrm{d}, J=12 \mathrm{~Hz}, \mathrm{CH}), 2.28(1 \mathrm{H}, \mathrm{d}, J=12 \mathrm{~Hz}, \mathrm{CH}), 2.30(1 \mathrm{H}, \mathrm{d}, J=16$ $\mathrm{Hz}, \mathrm{CH}), 2.41(1 \mathrm{H}, \mathrm{d}, J=16 \mathrm{~Hz}, \mathrm{CH}), 4.70(1 \mathrm{H}, \mathrm{d}, J=4.8 \mathrm{~Hz}, \mathrm{CH}), 5.28(1 \mathrm{H}, \mathrm{dd}, J=4.8 \mathrm{~Hz}$, $J=1.2 \mathrm{~Hz}, \mathrm{CH}), 5.80(1 \mathrm{H}, \mathrm{S}, \mathrm{NH}), 7.09-7.26(4 \mathrm{H}, \mathrm{m}, \mathrm{ArH}), 7.28-7.35(4 \mathrm{H}, \mathrm{m}, \mathrm{ArH})$. Anal Calcd for $\mathrm{C}_{24} \mathrm{H}_{24} \mathrm{ClNO}$ : C, 76.03; H, 6.30; N, 4.00. Found(\%): C, 76.28, H, 6.40; N, 3.71

3i: $\mathrm{v}_{\max } \mathrm{cm}^{-1} 3230,3050,2950,2870,1660,1580,1490,810,760,695 ; \delta_{\mathrm{H}} 1.04\left(3 \mathrm{H}, \mathrm{s}, \mathrm{CH}_{3}\right)$, $1.12\left(3 \mathrm{H}, \mathrm{s}, \mathrm{CH}_{3}\right), 2.18(1 \mathrm{H}, \mathrm{d}, J=16 \mathrm{~Hz}, \mathrm{CH}), 2.25(1 \mathrm{H}, \mathrm{d}, J=16 \mathrm{~Hz}, \mathrm{CH}), 2.31(1 \mathrm{H}, \mathrm{d}, J=16$ $\mathrm{Hz}, \mathrm{CH}), 2.41(1 \mathrm{H}, \mathrm{d}, J=16 \mathrm{~Hz}, \mathrm{CH}), 4.72(1 \mathrm{H}, \mathrm{d}, J=5.2 \mathrm{~Hz}, \mathrm{CH}), 5.31(1 \mathrm{H}, \mathrm{dd}, J=5.2 \mathrm{~Hz}$, $J=1.2 \mathrm{~Hz}, \mathrm{CH}), 5.95(1 \mathrm{H}, \mathrm{S}, \mathrm{NH}), 7.08-7.28(4 \mathrm{H}, \mathrm{m}, \mathrm{ArH}), 7.36-7.44(5 \mathrm{H}, \mathrm{m}, \mathrm{ArH})$. Anal Calcd for $\mathrm{C}_{24} \mathrm{H}_{25} \mathrm{NO}$ : C, 83.82; H, 7.41; N, 4.14. Found(\%): C, 83.93; H, 7.34; N,4.08.

\section{Results and Discussion}

The effects of the reaction conditions on yields of compounds $\mathbf{3}$ are summarized in Table 1. Firstly, the mixture of 5, 5-dimethyl-1, 3-cyclohexane-dione (2), 1, 3-phenol -2-propen-1-one (1a) and ammonium acetate was chosen as the model reaction to detect the proper distance from IR lamp for this reaction. When the distance is $5 \mathrm{~cm}, 10 \mathrm{~cm}$ and $20 \mathrm{~cm}$, the yields of $3 \mathbf{a}$ are $40.4 \%, 83.0 \%$ and $76.5 \%$ respectively. At a distance of $10 \mathrm{~cm}$, reaction of $\mathbf{1 a}, 2$ and ammonium acetate for $2 \mathrm{~h}, 3 \mathrm{~h}, 4 \mathrm{~h}$ and $5 \mathrm{~h}$, afford $\mathbf{3 a}$ in $53.7 \%, 83.0 \%, 82.4 \%$ and $83.1 \%$ yield respectively.

From the results above, the reaction conditions we chose are: the reaction time is $3 \mathrm{~h}$ and the distance is $10 \mathrm{~cm}$. Using the present method we did a series of experiments for synthesis of substituted 5-oxo-1, 2, 3, 4, 5, 6, 7, 8-octahydroquinoline derivatives (3a-3i), the results were summarized in Table 2 .

Wang ${ }^{9}$ reported the synthesis of 3a in DMF. However, we stirred 2, 1a and ammonium acetate in the same condition which resulted in a poor yield of 3a. We prolonged the reaction time from $2 \mathrm{~h}$ to $5 \mathrm{~h}$; the yield of $\mathbf{3 a}$ was only increased to $28.6 \%$ (Table $2, \mathbf{3} \mathbf{a}^{\boldsymbol{A}}$ ). Using this procedure, the yield of $\mathbf{3 a}$ was lower than that of reported.

In addition, when the distance is $10 \mathrm{~cm}$ from IR lamp we measured the reaction temperature, which was $80^{\circ} \mathrm{C}$. To compare the effectiveness of infrared irradiation method with stirring 
method, we stirred 1, 2 and ammonium acetate in the absence of solvent at $80{ }^{\circ} \mathrm{C}$ for $3 \mathrm{~h}$. The yield of $\mathbf{3 a}$ was $73.8 \%$ (Table $2, \mathbf{3 a}^{\boldsymbol{B}}$ ), and lower than that of infrared irradiation method.

Table 1. The Effects of the Reaction Conditions on the Yield of Substituted 5-Oxo-1, 2, 3, 4, 5, 6, 7, 8-Octahydroquinoline Derivatives

\begin{tabular}{cccc}
\hline Entry & Distance from IR lamp/cm & Time/h & Yield*/\% \\
\hline $\mathbf{1}$ & 5 & 3 & 40.4 \\
$\mathbf{2}$ & 10 & 3 & 83.0 \\
$\mathbf{3}$ & 20 & 3 & 76.5 \\
$\mathbf{4}$ & 10 & 2 & 53.7 \\
$\mathbf{5}$ & 10 & 3 & 83.0 \\
$\mathbf{6}$ & 10 & 4 & 82.4 \\
$\mathbf{7}$ & 10 & 5 & 83.1 \\
\hline
\end{tabular}

*Yields of pure isolated product

${ }^{a}$ The reaction temperature of different distance from IR lamp

Table 2 The Substituted 5-Oxo-1,2,3,4,5,6,7,8-Octahydroquinoline Derivatives Synthesized by 5,5-Dimethyl-1,3-Cyclohexane-Dione, Ammonium Acetate and 1,3-Diaryl-2-Propen-1-

One in Absence of Solvent Under Infrared Irradiation

\begin{tabular}{ccccc}
\hline Entry & $\mathrm{Ar}$ & $\mathrm{Ar}$ & Yield*/\% & M.P. $/^{\circ} \mathrm{C}\left[\mathrm{Ref}^{9}\right]$ \\
\hline $\mathbf{3 a}$ & $\mathrm{C}_{6} \mathrm{H}_{5}$ & $\mathrm{C}_{6} \mathrm{H}_{5}$ & 83.0 & $206-208[206-208]$ \\
$\mathbf{3 a}^{A}$ & $\mathrm{C}_{6} \mathrm{H}_{5}$ & $\mathrm{C}_{6} \mathrm{H}_{5}$ & 28.6 & $206-208$ \\
$\mathbf{3 a}^{\boldsymbol{B}}$ & $\mathrm{C}_{6} \mathrm{H}_{5}$ & $\mathrm{C}_{6} \mathrm{H}_{5}$ & 73.8 & $206-208$ \\
$\mathbf{3 b}$ & $4-\mathrm{ClC}_{6} \mathrm{H}_{4}$ & $\mathrm{C}_{6} \mathrm{H}_{5}$ & 85.4 & $224-226[224-226]$ \\
$\mathbf{3 c}$ & $3,4-\left(\mathrm{CH}_{3} \mathrm{O}\right)_{2} \mathrm{C}_{6} \mathrm{H}_{3}$ & $\mathrm{C}_{6} \mathrm{H}_{5}$ & 76.9 & $236-238[236-238]$ \\
$\mathbf{3 d}$ & $\mathrm{C}_{6} \mathrm{H}_{5}$ & $4-\mathrm{ClC}_{6} \mathrm{H}_{4}$ & 78.5 & $212-214[250-252]$ \\
$\mathbf{3 e}$ & $3,4-\left(\mathrm{CH}_{3} \mathrm{O}\right)_{2} \mathrm{C}_{6} \mathrm{H}_{3}$ & $4-\mathrm{ClC}_{6} \mathrm{H}_{4}$ & 86.5 & $250-252[176-177]$ \\
$\mathbf{3 f}$ & $3-\mathrm{ClC}_{6} \mathrm{H}_{4}$ & $\mathrm{C}_{6} \mathrm{H}_{5}$ & 79.6 & $225-227$ \\
$\mathbf{3 g}$ & $2,4-\mathrm{ClC}_{6} \mathrm{H}_{4}$ & $\mathrm{C}_{6} \mathrm{H}_{5}$ & 70.4 & $204-206$ \\
$\mathbf{3 h}$ & $4-\mathrm{CH}_{3} \mathrm{C}_{6} \mathrm{H}_{4}$ & $4-\mathrm{ClC}_{6} \mathrm{H}_{4}$ & 67.6 & $234-236$ \\
$\mathbf{3 i}$ & $4-\mathrm{CH}_{3} \mathrm{C}_{6} \mathrm{H}_{4}$ & $\mathrm{C}_{6} \mathrm{H}_{5}$ & 75.1 & $213-215$ \\
\hline
\end{tabular}

* Yields of pure isolated product.

${ }^{A}$ : Stirring for $5 \mathrm{~h}$ at $80^{\circ} \mathrm{C}$ using DMF as solvent.

${ }^{B}$ : Stirring for $3 \mathrm{~h}$ at $80{ }^{\circ} \mathrm{C}$ in the absence of solvent.

Varying the substituents on the benzene ring of 1, 3-diaryl-2-propen-1-one did not detrimentally affect the yields of compound 3. 1, 3-Diaryl-2-propen-1-one containing election-withdrawing groups and election-donating groups on the benzene were reacted well to give the corresponding 5-oxo-1, 2, 3, 4, 5, 6, 7, 8-octahydroquinoline derivatives (3b-3i) in good yields. 


\section{Conclusions}

We have found a clean and easy method for the preparation of the substituted 5-oxo-1, 2, 3, 4, 5, 6, 7, 8-octahydroquinoline derivatives. This method provides many obvious advantages such as the avoidance of discharging harmful organic solvent, the simplicity of the work-up, good yields, being environmentally friendly and using the safe and easily obtained IR lamp. The results showed that infrared irradiation can be used as a valuable means for synthesis of organic compounds.

\section{References}

1 Suárez M, Verdecia Y, Illescas B, Martínez-Alvarez R, Alvarez A, Ochoa E, Seoane C, Kayali N and Martín N, Tetrahedron., 2003, 59(46), 9179

2 Mauzerall D and Westheimer F H, J. Am. Chem. Soc., 1955, 77(8), 2261.

3 Stout D M and Meyers A I, Chem. Rev., 1982, 82(2), 223.

4 (a) Chorvat R J and Rorig K J, J. Org. Chem., 1988, 53(24), 5779. (b) Guzman A, Romero M Maddox M L and Muchowski J M, J. Org. Chem., 1990, 55(22), 5793. (c) Kappe C O, Tetrahedron., 1993, 49(32), 6937.

5 (a) Kidwai W, Sapra P, Bhushan K R and Misra P, Synthesis, 2001, 10, 1509. (b) Kidwai W and Sapra P, Synth. Commu., 2002, 32(11), 1639.

6 Guillermo Penieres C, Imelda Bonifas A, José Guadalupe López C, José Guadalupe Garcia E and Cecilio Alvarez T, Synth. Coтmu., 2000, 30(12), 2191.

7 Alcerrca G, Sanabria R, Miranda R, Arroyo G, Tamariz J and Delgado F, Synth. Сотти., 2000, 30(7), 1295.

8 Obrador E, Castro M, Tamariz J, Zepeda G, Miranda R and Delgado F, Synth. Commu., 1998, 28(24), 4649.

9 Xiang-Shan Wang, Da-Qing Shi and Shu-Jiang Tu, Synth.Commu., 2002, 32, 3449. 


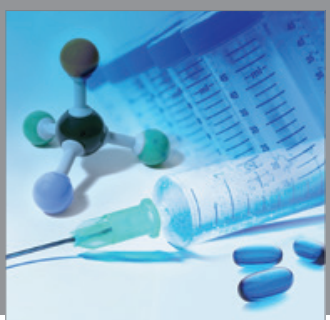

International Journal of

Medicinal Chemistry

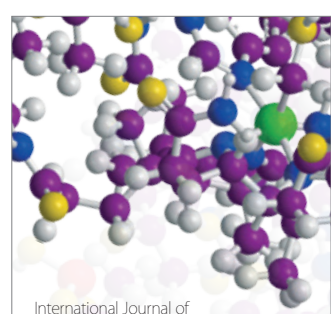

Carbohydrate Chemistry

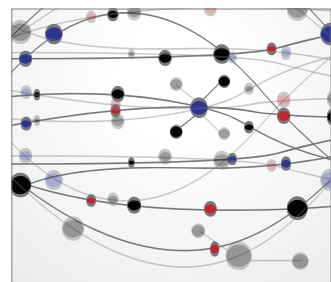

The Scientific World Journal
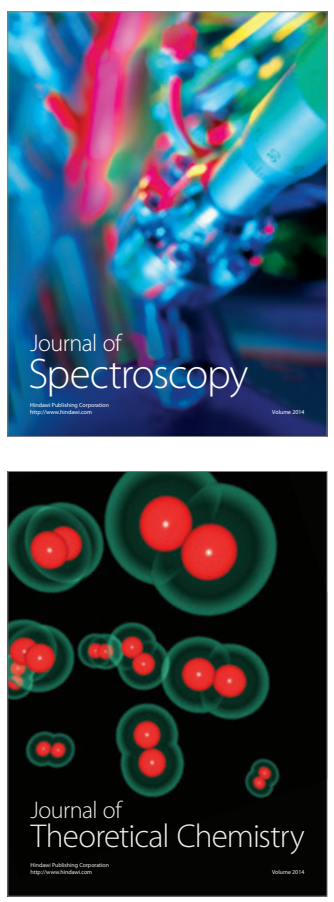
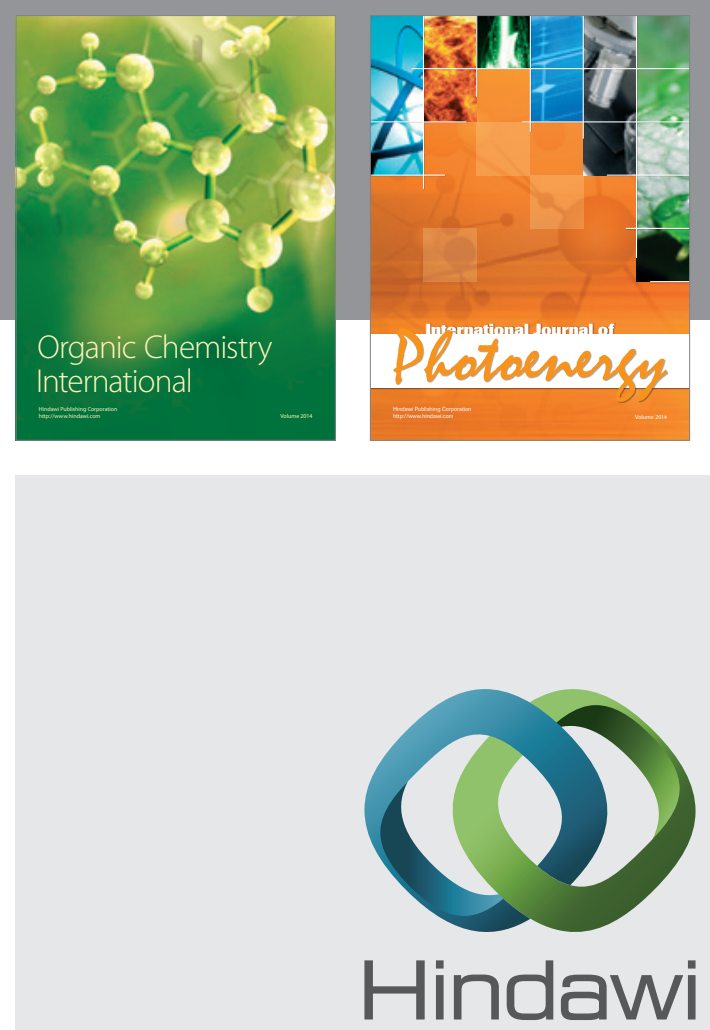

Submit your manuscripts at

http://www.hindawi.com
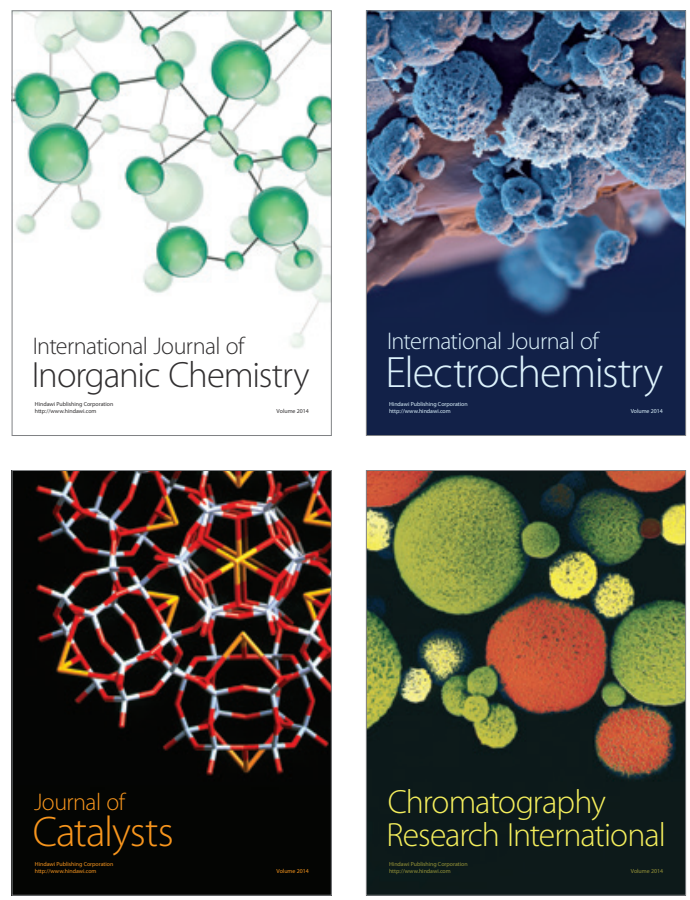
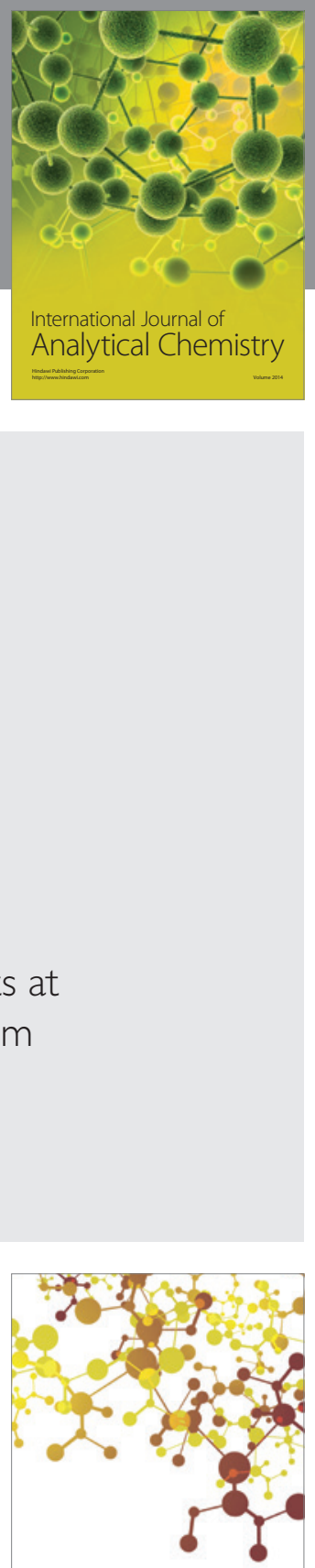

Journal of

Applied Chemistry
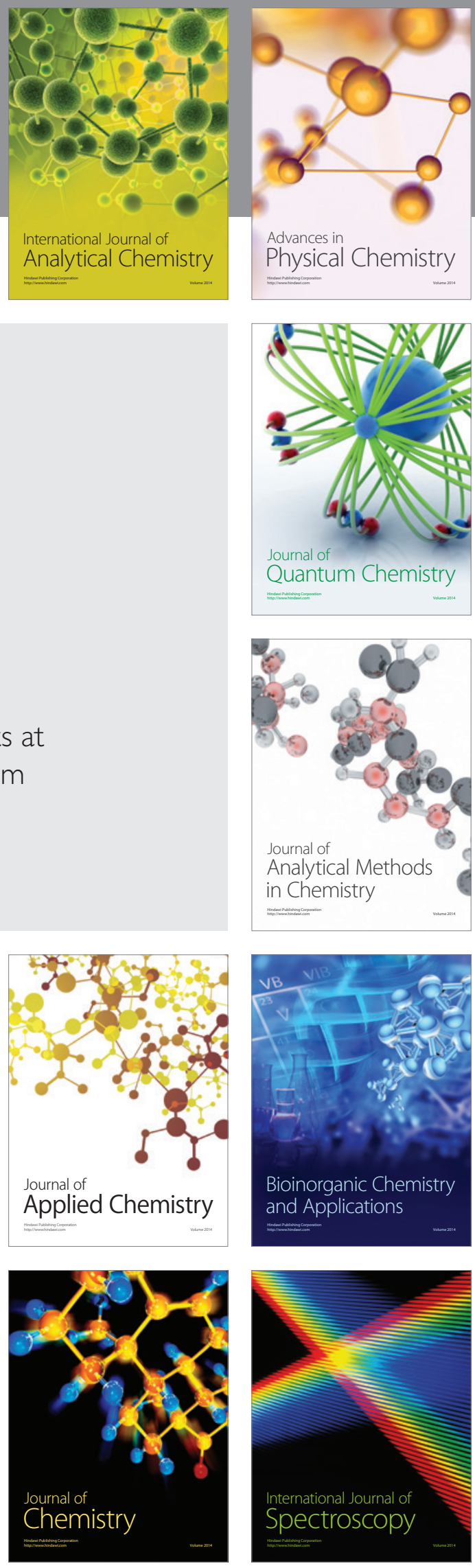